\title{
REVIEW
}

\section{Review of the Ochsenius Theory for Salt Generation in the Transylvanian Basin, Romania}

\author{
Unger, $Z^{1,2^{*}}$ LeClair, D. $^{2}$ \\ 1. ELTE University, Geographical Department in Szombathely, Hungary \\ 2. Oil \& Gas Development Central LTD, Budapest, Hungary
}

\section{ARTICLE INFO}

Article history

Received: 04 October 2021

Revised: 22 December 2021

Accepted: 30 December 2021

Published Online: 08 January 2022

Keywords:

Sedimentology

Salt generation

Stratigraphy

Historical records

\begin{abstract}
This short study aims to highlight contradictions in Ochsenius's model for the basin-wide salt generation (Kara-Bogas bay desiccation). Without claiming completeness, and through numerous records cited from the specific literature, we attempt to point at crucial incoherencies in the classical evaporitic model. In our presupposition, these might have led our ancestors to conclude that basin-wide salt generation needs theoretically well-based models. This is emphatically true for the Transylvanian Basin, Romania.The selected records are basic for the specific topic. We checked their validity by logical reasoning and by literature references.As for salt generation, the classical Ochsenius model has been upheld for the generation of evaporates even though it has been known that there are records denying the exclusivity of the evaporation model. It has also been proven that deep-sea salt exists, yet terminology is reluctant to follow the new discoveries. If non-evaporitic salt generation exists, it entails that huge salt deposits may exist, which are not remnants of a desiccation process. These cannot be considered as part of the classical theory of evaporation. Former researchers left important but neglected records, which should have updated the model of Ochsenius by now. Well-documented historical observation uncovered some contradictions in the salt generation of the Transylvanian Basin, Romania.Hereby we list 10 important contradictions, which may reveal that the well-known theory of Ochsenius (i.e. drying of

Kara Bogaz bay) ought to be challenged for the Transylvanian Basin.
\end{abstract}

happen in a shallow- or in an isostasy-driven deep basin. It is to be mentioned that the water of the basin is always shallow in these cases ${ }^{[3]}$.

Besides this evaporation model, the origin of salt on Earth was attributed to the hydrothermal processes with the other evaporites, were formed by the desiccation of a basin, driven by solar evaporation ${ }^{[1,2]}$. This can

\section{Introduction}

It is commonly accepted that salt deposits, together 
described by Hovland et.al. ${ }^{[4]}$ through the precipitation of sub-surface boiling and supercritical water.

A new salt generation model was presented by Unger\&LeClair ${ }^{[5]}$ describing the deep hypersaline brine generation model as initiated by membrane polarisation, and generating a semipermeable membrane through a critical coagulation process. Reverse osmosis takes place releasing the water through this membrane; as a result, hypersaline brine is formed under the membrane, and salt will form in geological time scale.

This theoretical study scrutinizes the special literature, highlighting certain contradictory elements in the salt generation processes described, especially those from the Transylvanian Basin, Romania. Based on new exploration results ${ }^{[-9]}$, the classical idea of the evaporation model from the Middle Miocene seems to fail. Unfortunately, the historical records of travellers and researchers ${ }^{[10]}$ have been neglected despite the importance of these observations. They have been considered as having a local character only.

Hereby we list 10 important contradictions, which may reveal that the well-known theory of Ochsenius, (i.e. drying of Kara Bogaz bay) ought to be challenged for the Transylvanian Basin. This relevance can be shown in a redrawn sedimentary basin evolution model of nonevaporitic deep-sea salt generation, without tackling evaporation processes, as it is not the task of the present article.

Starting from the idea that no intensive salt producing environment exists currently, Krézsek et al. ${ }^{[7]}$ shows by system tract analysis the existence of deep-sea environment for the Middle Badenian, i.e. for when the salt was formed in the Transylvanian Basin, Romania. Furthermore, the top salt formation is missing, no fossils were found from the desiccated sea, and there are no extra-basinal deposits after the desiccation. Based on these and further similar arguments, we sustain that it is hardly possible for those giant salt deposits in the Transylvanian Basin, Romania, to have been generated according to the Ochsenius model.

\section{Methods and Materials}

Taking under a critical view some of the special literature records, we highlight the theoretical contradiction between the data and theories.

\subsection{Theoretical Geology}

Theoretical physics is a branch of physics that employs mathematical models and abstractions of physical objects and systems to rationalize, explain and predict natural phenomena. A physical theory is a model of physical events. Physical theories become accepted if they are able to make correct predictions.

Predictions are also crucial in geology, especially in resource estimation, where scientists are forced to cooperate with other specialists, to predict as correctly as possible the amount of resources to be produced or mined.

Geology started as a descriptive science and developed into an empirical science. Geology jumped directly to empirical science, skipping the stage of theoretical science ${ }^{[11]}$. The gap of theoretical geology is left open and needs to be filled ${ }^{[12]}$.

A rock is considered an output of sedimentary processes, resulting from input sediments. The relation between the input and output can be of three types (Figure $\left.1^{[11]}\right)$ :

- unique, each input has one output;

- convergent, several inputs have one output and

- divergent, one input has several outputs.

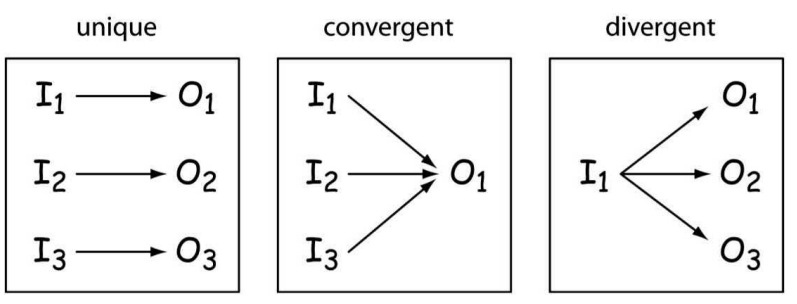

Figure 1. Possible deductive input-to-output paths, from ${ }^{[1]}$;

It is obvious that the correspondence is conclusive only in the case of unique relations (the first chart). The relation is non-conclusive both in convergent and divergent relation cases. In case of the evaporites, so far it has been considered that salt, gypsum, etc. come exclusively from evaporation. Nevertheless, it has been proved that these outputs can come from different sources; as a consequence, the convergent relation is valid for the generation of evaporites.

When we have evaporites, we deduce that the climate was arid, with intensive evaporation, and vice-versa: when we have arid climate, we are looking for the evaporate sequence to occur. These relations are only coincidences, no proofs. Theoretically, proofs need to come from a different level.

As per Chart 2 of Figure 1, Output 1 (O1) type salt can be generated in three different ways. Input 1 (I1) is the evaporation model by Ochsenius, Input 2 (I2) is the precipitation model from supercritical water by Hovland et al., and Input 3 (I3) is the hypersaline anoxic brines model by Unger \& LeClair. Accordingly, salt cannot be exclusively considered to be the result of the evaporation model (I1). We can only decide which salt generation 
method yields basin-wide deposits if we adopt the above theoretical models.

\subsection{Badenian Salt from the Transylvanian Basin (Romania)}

The origin of the Badenian Salt has been a crucial question in the Transylvanian Basin (Romania). Several contemporaneous and historical arguments exist against the earlier evaporation model, which seems to prove that we face the convergent relation regarding the input sediments and output rock.

The Transylvanian Basin (TB, Romania) is situated in the eastern part of the Carpathian Basin (Figure 2) between the Eastern Carpathian and Apuseni Mountains, and between the Southern Carpathian and Maramureș Mountains. As an important hydrocarbon province, it has always been the focus of exploration in the last century. Initially, potential potassium salt (sylvine) exploration attracted the geologists to this region ${ }^{[13]}$, and later dry gas was found indeed.

The complicated geological build-up and evolution of the Transylvanian Basin is well documented in several upto-date publications ${ }^{[5-8,14,15]}$ (Figure 4).

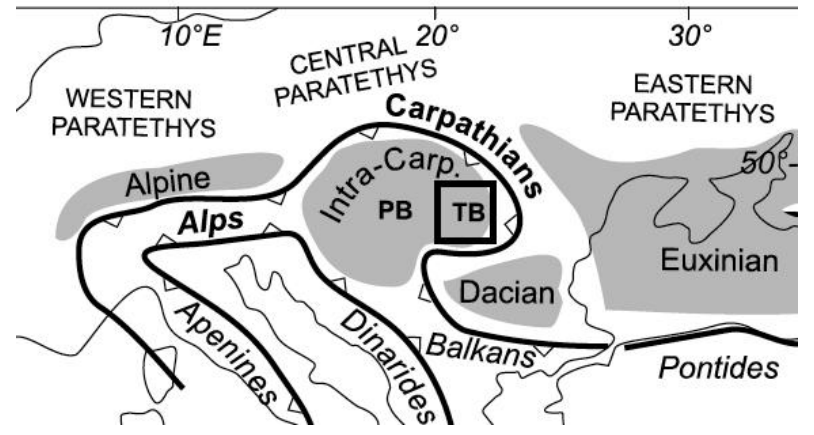

Figure 2. Location of the Transylvanian Basin - Romania in the Paratethys Range

TB - Transylvanian Basin, PB - Pannonian Basin

The Transylvanian Miocene sedimentary basin was part of the Central Paratethys and it is considered as a piggyback, cold basin, with a thick lithosphere ${ }^{[14]}$ in contrast with the Pannonian Basin, with thin lithosphere of elevated thermic gradient. The Transylvanian Basin, due to the thick lithosphere, is considered to be a cold basin.

The Transylvanian Basin hosts important gas reserves in the post-salt deposits with characteristic salt tectonics that have been studied by several researchers starting from 1911 until nowadays ${ }^{[6-8,14-18]}$. The origin of the exclusively methane reserves is a matter of standing debate since a secondary gas source is expected to be found in addition to the classic biogenic source, to amount to the actual methane reserves and production ${ }^{[5]}$.

Travellers and researchers of the last few centuries recorded a few contradictions in the classical salt generation model, i.e. evaporation. Researchers neglected all those observations, dismissing them as a rudimentary stage of exploration, for hundreds of years. Else, they were considered only of local interest and not as characteristic basin-wide. Despite all these, we are convinced that our professional ancestors were learned and committed specialists of their time. Hence, we ought to pay more attention to their precise records ${ }^{[10]}$.

The ice of forgetting was broken by Krézsek et al. (2010) ${ }^{[7]}$ when they proved that, according to the system tracts analysis (Figure 3), the salt was embedded between deep-sea deposits, i.e. this salt has deep-sea origin. The mechanism of the deep-sea salt-generation has so far remained unexplained by the authors.
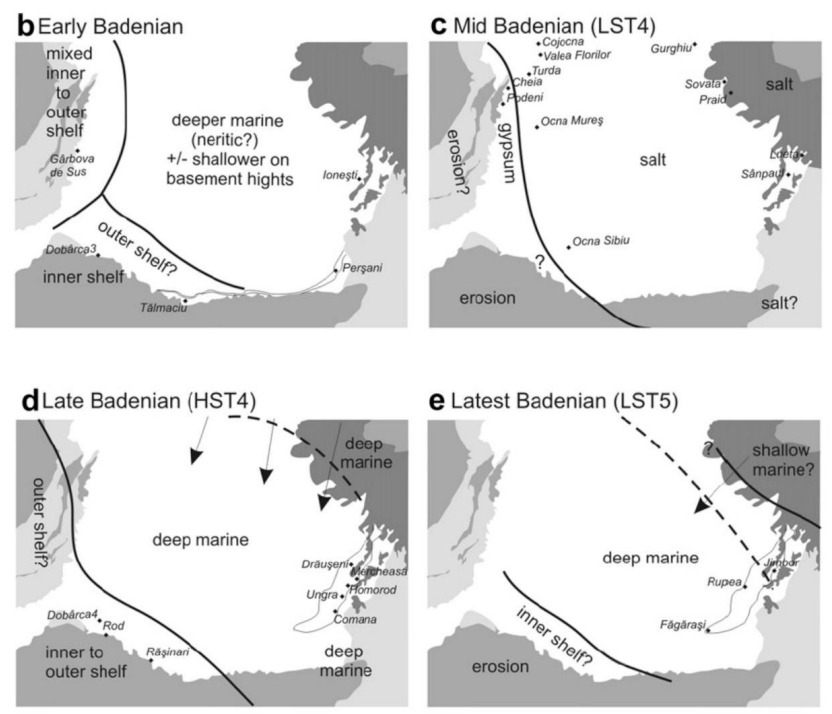

Figure 3. System tracts analysis for the Transylvanian basin

(selected Miocene periods from Krézsek et al. 2010. Figure $9^{[7]}$ )

In our view, in concordance with Krézsek et al. 2010 ${ }^{[7]}$, this deep-sea salt cannot be considered as remnant precipitation of the evaporated seawater, which the Transylvanian salt is considered to be. As a result, the theoretical geology reached a landmark and we propose that not all salts can be considered as having evaporitic origin (see: Figure 1. convergent relation).

\section{Contradiction in Salt Generation}

Hereby we intend to list ten facts, which are in contradiction with the classical evaporation model, Ochsenius\&Van't Hoff theory in Arrhenius \& Lachman (2003) ${ }^{[19]}$ in the Transylvanian Basin, Romania. 
It is a conspicuous fact, also documented in San Francisco Bay, that the evaporation produces a wellknown series of precipitates. Starting with a calcareous deposit $\left(\mathrm{CaCO}_{3}\right)$ precipitation, the second stage is gypsum $\left(\mathrm{CaSO}_{4} * 2 \mathrm{H}_{2} \mathrm{O}\right)$ followed by the table salt $(\mathrm{NaCl})$ formation, and the succession ends with the so called "covering salts" as cap rock: sylvine, Glauber's- and Epsom salt, etc. $\left(\mathrm{KCl}, \mathrm{Na}_{2} \mathrm{SO}_{4} * 10 \mathrm{H}_{2} \mathrm{O}, \mathrm{MgSO}_{4} * 7 \mathrm{H}_{2} \mathrm{O}\right){ }^{[20]}$.

\subsection{Missing of the Top Salt Formation}

This latest top salt, cap rock formation is missing from the Transylvanian Basin. As of this day nobody has proved the existence of a top salt formation. Although finding sylvine was the main target for the well Kissármás-2, instead of potassium salt they discovered the methane reserves in the Transylvanian Basin ${ }^{[13]}$ instead of potassium salt. On sites where salt diapirs outcrop in the Transylvanian Basin, there is no evidence for top salt formation, and only table salt $(\mathrm{NaCl})$ is documented. These statements are also supported by numerous drillings from the Basin. Our site visit in the mine and several sample collections (Ocna Dejului, Praid) did not prove the existence of cap rock salt.

\subsection{The Continental Origin of Salt}

In our view, the salt content of the oceans does not come from onshore. Generally, the catchment area of the inflowing rivers as a background is not as salty as to transport salt solution into the oceans. This is valid for the Transylvanian Basin, too; it is only in basin deposits that salt deposits are hosted.

As an example: nowadays creek Corund/Korond flows through the salt dome of Praid, creating a spectacular canyon, and dissolving a significant amount of salt. In spite of the permanent solvation of the salt, the amount of salt that the creek transports $\left(2850 \mathrm{mg} / \mathrm{L},{ }^{[21]}\right)$ does not turn the affluent Târnava Mică/Kis-Küküllő River salty; beyond a $5 \mathrm{~km}$ distance no dissolved salt can be measured.

A second example is salty lake Alune near Târnăveni, Romania, wherefrom Valea Sărata Creek transports a minor, but undetectable amount of salt to the same Târnava Mică/Kis-Küküllő River without turning the water of the river salty.

\subsection{There is No Actual Intensive Salt Producing Environment}

Building on the basic idea of Charles Lyell, Arrhenius \& Lachman ${ }^{[19]}$ state that there is no actual facies on the Earth capable of producing basin-wide salt amounts. The Ochsenius model (the Kara Bogaz bay desiccation) produces only thin salt layers.

Warren ${ }^{[22]}$, in the Encyclopedia of Geology ( $2^{\text {nd }}$ edition) on page 965, Figure 15., draws a schematic cross section of ancient evaporite settings especially for "Basinwide evaporites", the brine of which is fed by saline springs through the marine barriers. The author mentions that there is "no modern analogues". Then the model may not be well-founded.

In our view there are two possibilities:

- either that geologists will keep looking for actual giant salt generation environments;

- or that theoretical geology will create a model (similarly to the case of banded iron, which is not formed in any nowadays' environment), as to how basin-wide salt can be created.

\subsection{Salt Amount and Climate Conditions}

The thickness of the salt layer in the Transylvanian Basin is assumed to vary from $500 \mathrm{~m}$ to $300 \mathrm{~m}$. Yet, according to the only well-documented thickness datum by Stoica\&Gherasie ${ }^{[23]}$, the salt deposit is $250 \mathrm{~m}$ thick. If we consider this figure, the evaporated amount of seawater corresponds to a column of $\sim 20000 \mathrm{~m}$ seawater, which leaves behind a salt amount the like of which we have in the Transylvanian Basin (i.e. 100 feet seawater produces 2 feet salt). It was observed that $1000 \mathrm{~m}$ sea water of normal salinity produces $12.5 \mathrm{~m}$ salt ${ }^{[24]}$. Considering the above, it is not particularly plausible that such an enormous quantity of seawater could evaporate from the Transylvanian Basin. An immediate question rises: What climate can produce such an evaporation process (insolation + evaporation + wind) to dry out a basin of this amount of water, and produce basin-wide salt deposits? There is no need for calculation; it is obvious that such climate does not exist on Earth.

\subsection{Time and Duration of the Evaporation}

Another contradictory issue refers to the time and duration of the dry-out of the basin. It was proven that the salt in the Transylvanian Basin had been formed in the Middle Badenian, i.e. it is more than 13 Ma old ${ }^{[8]}$.

The BSC evaporite deposition is dated at $13.81 \pm 0.08$ Ma and the entire event is estimated to have lasted 200600 k.y. in the Paratethys range ${ }^{[25]}$.

For the Transylvanian Basin, the same authors, de Leeuw et al. ${ }^{[26]}$ place the evaporitic age between 14.38 $\sim 13.36( \pm 0.06)$ Ma, i.e. $\sim 1.02 \mathrm{Ma}$ duration based on radiometric tuffitic age determination. Similar ages were published by Szakács et al. ${ }^{[27]}$ about the age of the Dej Tuff formation, which also represents the base of the BSC 
formation in certain places.

The so-called Messinian (MSC) evaporitic age was not longer than $0.4 \mathrm{Ma}^{[28]}$ in the Paratethys Range. As a consequence, the intensive evaporation period that produced $\sim 250 \mathrm{~m}$ thick salt in the Transylvanian Basin must have taken place in one million years, which, again, is not very plausible.

\subsection{Lack of Fossils}

If a basin dried out, we would have to find fossils which had lived in the seawater from the former, pre-salt sedimentary basin. Yet there is no such evidence found that "the salt deposits contain no fossils (petrifactions)" [19]. Moreover, Leeuw et al. ${ }^{[26]}$ mentions that "no microfauna" was found from the BSC period in the Transylvanian Basin.

\subsection{Lack of the Covering Clastic Deposits over the Salt Deposits in the Desiccated Basin}

After the evaporation process, one can expect the occurrence of the coarse clastic extra- basin deposits, which are products of the surface erosion from the surrounding, elevated, positive geomorphological terrains. In this case there is no evidence for such extra-basin deposit occurrence...

\subsection{Deep-Sea Sediments and Subsidence Rate}

...notwithstanding, there are well documented intra-basin deposits. These are marls with Radiolaria and Spiratella fossils, which cover the Transylvanian salt deposits ${ }^{[8]}$, proving the existence of a deep-sea environment (Figure 4).

Moreover, Leeuw et al. ${ }^{[26]}$ shows that under the BSC formation, there can be found marly deposits with Globorotalia bykovae, Globigerinopsis grilli and Orbulina suturalis.

Bojar et al. ${ }^{[29]}$ and Filipescu \& Filipescu ${ }^{[30]}$ describe similar microfauna highlighting that this represents a transgressive cold seawater sequence, and not a shallowing warm water environment that precedes the desiccation of the basin.

In the same figure "deep marine" deposits are shown over the halite deposit, which was described already in 2005 by Krézsek \& Filipescu ${ }^{[31]}$ as deep marine environment marked by the Velapertina zone.

Therefore, the main contradiction is the subsidence rate; it is less plausible that such a quick subsidence rate on a desiccated sea/lake needs to turn from an extra-basin facies into a deep intra-basin facies, suffering an intensive transgression that lacks the characteristic lithological footprint.

\subsection{Miocene System Tracts}

Krézsek et al. ${ }^{[7]}$ published the system tracts from the Early Badenian to the Late Sarmatian period with deep marine environment (p.206.) containing the salt deposits in the Transylvanian Basin. Here you can see the system tract under the salt and over the salt from the Early- to the Late Badenian (Figure 3). The existence of salt does not always prove regression and LST. If we have salt from

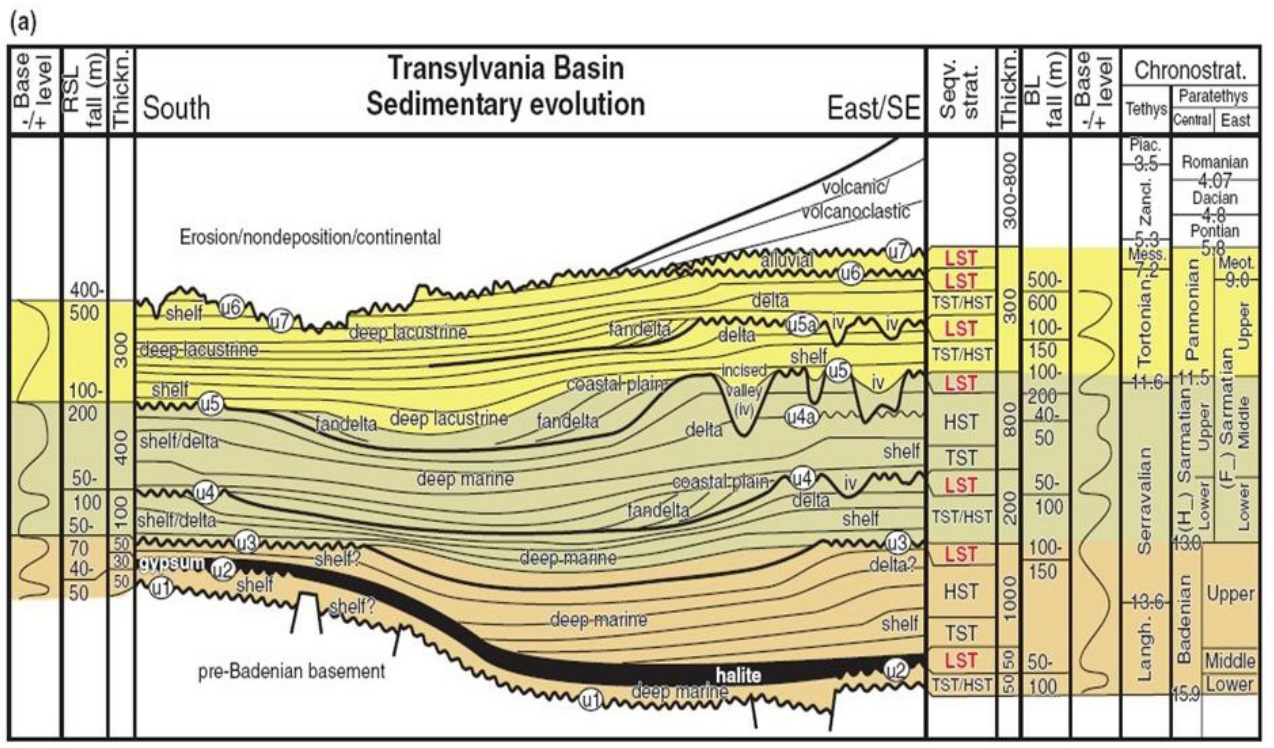

Figure 4. Stratigraphic chart of the Transylvanian Basin (courtesy of Mațenco et. al, 2010, for Figure 4a. ${ }^{[8]}$ ) 
precipitation by supercritical water ${ }^{[4]}$ or from buried deep hypersaline brines ${ }^{[5]}$, then the HST is continuous; there is no LST in the sedimentary sequence build-up.

\subsection{Records of Travellers and Researchers of Previous Centuries}

Several travellers and researchers made records about their Transylvanian journey, which were reedited in a volume by Alpár Miklós ${ }^{[10]}$. Our interest lay in highlighting their observations regarding salt in the mines they had visited. We can state as a matter of fact that, surprisingly, posterity did not take these into account. It is not clear why these records were neglected. Maybe because they did not support the generally acknowledged, classical idea about the evaporites. Let us draw a timeline of a few of these:

a. In 1770 Ignaz von BORN, when he visited Turda/ Torda/Thorenburg salt mine, mentioned in his letter dated on 28 July that salt layers are separated by argillaceous thin beds, which are smelly and kneadable. The "alabaster", the gypsum found in the surroundings is present in the majority of salt occurance locations and he assumed that it may have been formed due to the transformation of the "salt acid" into "vitriol", i.e. sulphuric acid.

This gypsum is classified simply as evaporite by the modern researchers; nobody has checked the geochemical validity of this consideration, nobody has denied it, which can be considered valid until somebody proves it to be false.

b. In 1786 Lazzaro SPALLANZANI considered that these rounded fragments of gypsum are the result of the transformation of the limestone into gypsum, continuing BORN's idea as mentioned above.

c. In 1789 Balthasar HACQUET visited Praid/ Parajd/Salzberg mine, where he noticed that the salt has various colours due to the argillaceous particle content. Furthermore, massive salt does not present idiomorphic crystals in a manner similar to ice, which crystals can be considered primary.

He also formulates the question "How is it possible that every salt deposit is covered by black bituminous clays?", i.e. deep marine deposits, and not extra-basin formation.

d. In 1794 Jens ESMARK mentions similar bituminous clay inclusions from the salt body in Turda/Torda/ Thorenburg and Ocna Dejului/Désakna/Salzgrube mines..

Furthermore, he mentions that the Polish and Transylvanian salts are linked in the deep underground (as folk tradition holds in the legend on Saint Kinga's ring).

e. In 1796 Pál KITAIBEL, the famous botanist and chemist describes the salt deposits accurately as being layered, folded in Ocna Şugatag/Aknasugatag mine. He mentions that it contains coal with a smelly character.

On the surface there existed a swampy area, maybe an abandoned mine, where the disturbed mud released a smelly gas which was burning with bluish flame.

f. In 1826 Johann Christian POGGENHOFFER published the observation of Johann Nepomuk BREMER, a pharmacist in Baia Mare/Nagybánya, about Solotvyno/ Aknaszlatina locality, where the methane from the salt mine was used for public lighting. This may have been the earliest of such usage worldwide. This proves that the salt body hosted gas trapped within.

g. In 1851 Carl J. ANDRA mentions that "the anhydrite/gypsum appears in knotty forms and always in sandstones, independently from the salt". It may be posited that they were formed independently from the salt deposits, with no evaporation.

h. In 1858 the "Österreichische Zeitschrift für Berg- und Hüttenwesen" magazine reported about a firedamp explosion from the salt mine from Turda/ Torda/Thorenburg. We have similar evidence from other salt mine firedamps from the 19th century from Ocna Dejului/Désakna/Salzgrube, Ocna Mureşului/Marosújvár/ Miereschhall, Ocna Sibiului/Vizakna/ /Salzburg and (Praid/Parajd/Salzberg) recorded by ZINCKEN,C.F., in 1890 [p.54.] (in ${ }^{[32]}$ ).

(The first known and documented firedamp occurred in Hallstadt on ${ }^{[33]}$ in the salt mine. Accordingly, we can deduce that salt formation has a link to methane generation, or at least hosting.)

i. As early as in $\mathbf{1 8 6 0}$ Bernhard von COTTA had doubts about the evaporation model of the Transylvanian salt.

j. In 1885 Antal KOCH noted that the freshly broken salt sample smells of bitumen.

$\mathrm{k}$. In the 1800s a similar phenomenon is described by Klára and Mihály TÖRÖK when they mention that the broken salt surface becomes progressively whiter as the methane is evaporated, and it smells of bitumen.

\section{Discussion}

Geology, especially sedimentary geology, reached a landmark when theoretical geology started to demand space in geology just as theoretical physics did centuries before. The sedimentary geological processes also need to be in concordance with the theoretical consideration. This has an impact also upon the geological terminology. Starting from the idea that evaporite deposits can have multiple origin as it was also highlighted on the recent Salzburg conference entitled "Evaporite Processes and Systems: Integrating Perspectives" (Oct. 18 - 20, 2021), 
we can state that not all evaporites (salt and gypsum) can be considered evaporites. Gypsum and salt deposits can have non-evaporitic origin. The sediment input in such convergent relation is not conclusive. As a result, those deep-sea; add hyphen evaporites cannot be considered as remnants of a drying, evaporation process.

This is the reason why in salt generation there are so many contradictory statements. Hereby we list 10 contradictions shown through a case-study based on published literature and field/mine observations.

The lack of top salt formations, the missing extra-basin deposits and fossils from the dried basins and the fact that there are no actual giant salt generation sedimentary environments demonstrate against evaporation basin. All these we consider valid for the Transylvanian Basin.

The underlying- and covering deposits of the salt formation are unanimously shown by several drillings from the Transylvanian Basin to be deep-sea deposits, proved by the micropaleontological determination and the system track mapping of the Early- to the Late Badenian environments.

The amount of salt generated in the Transylvanian Basin, together with the evaporation processes and the subsidence rate processes need to be concentrated in $\sim 1$ $\mathrm{Ma}$, as proved by the radiometric age determination of the tuffitic layer. All in all, evaporation and subsidence processes are less plausible.

Surprisingly, several historical records were neglected by the recent researchers; those could have been important observation made by our forerunners in order to lead the researchers to the non-evaporitic model of salt generation, true especially for the Transylvanian Basin.

The presence of methane, such as providing public lighting in Solotvina from the mine, or the registered firedamps prove the presence of methane in the salt body.

This means a hazard and an important risk to face, yet it should draw attention to questions regarding the origin of the methane.

\section{Conclusions}

The whole history of salt exploration will have a discordant character until the origin of the salt generation process is clarified. It is obvious that such a huge, basinwide salt amount cannot have been generated simply by evaporation ${ }^{[19]}$. Some other known processes are responsible for the salt deposit formation, as an alternative those described by Unger \& LeClair ${ }^{[5]}$. Gas occurrences in the salt deposits show parallel salt and methane generation, mentioned in Unger\&LeClair publication ${ }^{[9]}$. These serve as explanation for the contradiction listed in this article.
If we analyse the research records of the past few centuries, we can find important information so far neglected by modern researchers. These should not be overlooked by a simple categorisation, attributing them to just an early/"romantic" stage of research. This perspective creates contradictory models, which remain questionable. We trust that the ten contradictions listed above will urge researchers to update their ideas and models, and to rethink the interpretation based on existing records.

The theoretical approach of sedimentary geology will probably create severe criteria to separate the "KaraBogaz" model from the deep-sea evaporates, which we may need no longer call "evaporites" in the future.

We conclude that the Transylvanian Basin was a deep marine basin; the Badenian salt is not a remnant of the evaporation processes. There was no Badenian Salt Crisis (BSC) in the Transylvanian Basin.

Based on the 10 listed contradictions, it will be challenging to review in this new approach the other giant salt basins, especially those from the Outher Carpathians (Romanian Diapir Zone, the Cacica salt Mine from Bukovina-Romania, and Wieliczka Region from Poland). This will facilitate updating the research material from those salt basins, possibly of deep-sea origin.

\section{Author Contributions}

The authors have the same $50 \%-50 \%$ contribution to this article.

\section{Funding}

The research of the project entitled Parallel Salt and Methane Generation was supported by the Oil\&Gas Develoment Central Ltd. Hungary and Sandhill Petroleum Romania Ltd. This article is an integral part of the named project.

\section{Acknowledgments}

We express special thanks to Mr. Pete NOLAN (senior consultant) and Mr. David Westlund (Exploration Director at O\&GD) for permanent conversation and encouraging support, debates and essential expert advice. We express our gratitude to the colleagues for the critical opinion on listening to our new hypotheses.

\section{References}

[1] Warren, J., 2016. Evaporites, In book: Encyclopedia of Geochemistry.

DOI: https://doi.org/10.1007/978-3-319-391939 100-1

[2] Warren, J., 2010. Evaporites through time: Tectonic, 
climatic and eustatic controls in marine and nonmarine deposits, Earth-Science Reviews 98. pp. 217268.

DOI: https://doi.org/10.1016/j.earscirev.2009.11.004

[3] von Den Belt, F.J.G., de Boer, P.L., 2007. A shallow-basin model for 'saline giants' based on isostasy-driven subsidence, Spec. Publ. Int. Assoc. Sedimentol. 38, 241-252. ISBN: 978-1-444-30441-1.

[4] Hovland, M., Rueslåtten, H.G., Johnsen, H.K., Kvamme, B., Kuznetsova, T., 2006. Salt formation associated with sub-surface boiling and supercritical water, Marine and Petroleum Geology 23. pp. 855869.

DOI: https://doi.org/10.1016/j.marpetgeo.2006.07.002

[5] Unger, Z., LeClair, D., 2018. Salt and Methane Generation Initiated by Membrane Polarisation. Earth Sciences. 7(2), 53-57.

DOI: https://doi:10.11648/j.earth.20180702.12

[6] Krézsek, Cs., Bally, W.A., 2006. The Transylvanian Basin (Romania) and its relation to the Carpathian fold and thust belt: Insights in gravitational salt tectonics, Marine and Petroleum Geology 23. pp. 405442.

DOI: https://doi.org/10.1016/j.marpetgeo.2006. 03.003

[7] Krézsek, Cs., Filipescu, S., Silye, L., Mațenco, L., Doust, H., 2010. Miocene facies associations and sedimentary evolution of the Southern Transylvanian Basin (Romania): Implications for hydrocarbon exploration, Marine and Petroleum Geology 27. pp. 191-214.

DOI: https://doi.org/10.1016/j.marpetgeo.2009. 07.009

[8] Mațenco, L., Krézsek, Cs., Merten, S., Schmid, S., Cloething S., Andriessen P., 2010. Characteristics of collisional orogens with low topographic build-up: an example from the Carpathians, Terra Nova. 22, 155-165.

DOI: https://doi.org/10.1111/j.1365-3121.2010. 00931.x

[9] Unger, Z., LeClair, D., May 19-20 2016. Is the Badenian Salt Deposit in Transylvania a Secondary Source of Methane? (abs.): AAPG European Regional Conference and Exhibition, Abstract Book, Bucharest, Romania. pp. 112.

[10] Miklós, A., 2017. Foreign travellers' notes about the Transylvanian and Maramureș salt mines (18-19. century) Transylvanian Museum Society, People and Contexts. 14, 427. (In Hungarian) ISBN 978-606739-072-8.

[11] Mikeš, D., 2013. “Theoretic Geology - The gap be- tween empiric and mathematic geology". In: Mathematical Geosciences Special Issue - Theory, Methods and Applications. Ed. by S.M. Ernst, V. Liesenberg, and F. Shahzad. Inkaba yeAfrica contribution 85 . Chap. 1, pp. 7-25. ISBN 978-3-86012-453-6.

[12] Mikeš, D., 2010. Geophysical Research Abstracts Vol. 12, Bibcode: EGU2010-6614-1, 2010 EGU General Assembly. https://ui.adsabs.harvard.edu/ abs/2010EGUGA..12.6614M.

[13] Papp, K., 1911. Potasium salt exploration in Hungary. Geological Bulletin of the Hungarian Geological Society, Budapest. vol. XLI/41. pp. 1-19.

[14] Tiliță, M., Lenkey, L., Mațenco, L., Horváth, F., Dinu, C., 2006. Neogene evolution of Transylvania basin: insights derived from (2D steady-state) thermal modelling. Geophysical Research Abstracts 8, 08874. SRef-ID: 1607-7962/gra/EGU06-A-08874.

[15] Tămaş. D.T., Schléder, Zs., Krézsek, Cs., Man, S., Filipescu S., 2018. Understanding salt in orogenic settings: The evolution of ideas in the Romanian Carpathians, AAPG Bulletin. 102(6), 941-958.

DOI: https://doi.org/10.1306/0913171615517088

[16] Böckh, J., 1911. Notes about the anticlines with gas reserves from the Transylvanian Basin, Geological Bulletin of the Hungarian Geological Society, Budapest. vol. XLI. pp. 235-239.

[17] Paraschiv, D., 1979. Romanian Oil and Gas Fields, Institutul de Geologie și Geofizică, Studii Tehnice şi Economice/Geological and Geophysical Institute/ Technical and Economic Studies, vol. 13. Seria A, Bucharest. pp. 382.

[18] Nemeşan, M., 2007. Romgaz. Present and Perspectives. Energy in Centre and Eastern Europe Forum, Bucharest. 20-22.

[19] Arrhenius, S., Lachman, R., 2003. The physical-chemical conditions relating to the formation of salt deposits and their application to geologic problems. In: Milestones in Geosciences Ed.by Dr. Wolf-Christian Dullo. pp. 62-74.

DOI: https://doi.org/10.1007/s00531-002-0270-2

[20] http://omp.gso.uri.edu/ompweb/ opened at 12 March 2017.

[21] Rusz, O., 2014. The salt concentration changes of Corund creek, Abstract volume of EMF-BKF Odorheiu-Secuiesc conference. pp. 305-306. (In Hungarian) ISSN-1842-9440.

[22] Warren, 2021. Evaporite Deposits, In: Encyclopedia of Geology, 2nd edition, Elsevier Ltd. pp. 945-977. DOI: https://doi.org/10.1016/B978-0-08-1029084.00165-X

[23] Stoica, C., Gherasie, I., 1981. Salt, Potasium- and 
Magnesium-salt from Romania. Editura Tehnica, Bucuresti. pp. 248.(In Romanian)

[24] Pauca, M., 1967. Contribution to the Miocene salt genesis from Romania. Annual Report of the Geological Institute, LIII(2)(1965-1966). pp. 159-184.(In Romanian)

[25] de Leeuw, A., Bukowski, K., Krijgsman, W., Kuiper, K.F., 2010. Age of the Badenian salinity crisis; impact of Miocene climate variability on the circum-Mediterranean region, Geology. 38(8), 715-718. DOI: https://doi.org/10.1130/G30982.1

[26] de Leeuw, A., Filipescu, S., Maţenco, L., Krijgsman, W., Kuiper, K., Stoica, M., 2013. Paleomagnetic and chronostratigraphic constraints on the Middle to Late Miocene evolution of the Transylvanian Basin (Romania): Implications for Central Paratethys stratigraphy and emplacement of the Tisza-Dacia plate, Global and Planetary Change 103. pp 82-98. DOI: https://doi.org/10.1016/j.gloplacha.2012.04.008

[27] Szakács, A., Pécskay, Z., Silye, L., Balogh, K., Vlad, D., Fülöp, A., 2012. On the age of the Dej Tuff, Transylvanian Basin (Romania), Geologica Carpathica. 63(2), 139-148.

DOI: https://doi.org/10.2478/v10096-012-0011-9

[28] Gautier, F., Clauzon, G., Suc, J.P., Cravatte, J., Vi- olanti, D., 1994. Age et durée de la crise de salinité messinienne C.R. Acad. Sci. Paris. 318, 1103-1109.

[29] Bojar, H.P., Antoniade, C., Barbu, V., Bojar, A.V., 2020. A New Preparation Method of Microfauna from Gypsum: Micropaleontological Association from the Middle Miocene Badenian Gypsum Deposits of Paratethys, Geosciences. 10(158) 1-14. DOI: https://doi.org/10.3390/geosciences1005015

[30] Filipescu, R., Filipescu, S., 2015. New data on the Early - Middle Badenian transition in the NW Transylvanian Basin (Romania) revealed by the planktonic foraminifera assemblages, Studia UBB Geologia. 59(1-2), 39-44.

DOI: http://dx.doi.org/10.5038/1937-8602.59.1.3

[31] Krézsek, Cs., Filipescu, S., 2005. Middle to late Miocene sequence stratigraphy of the Transylvanian Basin (Romania). Tectonophysics. 410, 437-463.

[32] Wanek, F., 2008. The history of discovering natural gas reserves in the Transylvanian Basin from the death of Ferenc Nyulas to its re-discovery in 1908, Technical Review, 44. Historia Scientiarum - 5. Special Issue in History of Sciences). pp. 3-16.

[33] Harris, G.D., 1908. Rock salt, its origin, geological occurrences, and economic importance in the state of Louisiana; Louisiana Geol. Survey Bulletin. 7, 173. 